\title{
Discussion on Problems Real Exist in Estate Tax System Reform in Our Country and Strategy for Improvement Research
}

\author{
Yaopeng $\mathrm{Lin}^{1}$, Ting $\mathrm{CaO}^{2}$, Junhua $\mathrm{Li}^{2}$ \\ ${ }^{1}$ Zhuhai College of Jilin University, Zhuhai Guangdong, 519000, China \\ ${ }^{2}$ Macau University of Science and Technology, Macau, 999078, China
}

Key words: Real estate tax, Tax reform, Problems, Influence, Strategy.

\begin{abstract}
In recent years, the growing prosperity and radical reform of the real estate market in China can be considered as having become an important pillar industry of national economy in our country. As for real estate tax system reform, it should be designed based on various scientific elements, comprehensively perfecting the tax system and evaluating the real estate market problems, evading the phenomenon such as low taxes in the real estate keeping link, tax scope too narrow, unreasonable tax basis and at the same time preventing market speculation, wanton abuse of land resources and the housing bubble etc. This paper hopes to take the existing problems in the real estate tax system reform in our country as the background, mainly discussing the effective strategies of perfecting our country's real estate tax system reform.
\end{abstract}

\section{Introduction}

Real estate tax is one of the macroeconomic regulation and control means the country implements on the real estate market, It does not directly decide the house prices, but it can control the real estate market environment which determines the price. China's real estate market mechanism itself has limitations, so sometimes the effect on market regulation is not obvious, and there even exists market monopoly phenomenon. At this time it requires country to reform the property tax system, and then optimizing its use of regulation on the real estate market, guiding buyers' rational consumption, and ultimately balancing supply and demand of the real estate market. The real estate tax reform can be seen as the reconstruction of the real estate market able to provide good basis for market development, so as to realize the cycle effect of tax benign recycling.

\section{Problems exist during the process of our country's real estate tax System}

Since 1994, when the implementation of the tax assignment system reform in China, the estate tax reform has also been gradually improved and form a set of relatively sound and complete system of estate tax. And in recent years our country also began to set up pilot property tax levy in Beijing, Shanghai, Chongqing and other places. But in the process of implementation and practice development of the tax system, there are still many problems in its actual content. For this reason, this article will discuss the existing problems from two aspects including design and auxiliary system of the real estate tax system.

\section{Real estate tax system and elements design problems}

According to the Provisional regulations on the People's Republic of China urban state-owned land use right leasing and transferring issued and carried out in 1990 by the State Council, the land transfer fee is included in the real estate tax system. The land transfer fee refers to, the land user must pay taxes in accordance with relevant provisions of the national standard to the country when the land 
use within the limit of one year period transferred to the land user. From the aspect of real estate tax, land transfer fee belongs to non-tax nature revenue, not belonging to any kind of taxes. Land transfer fee is often paid one time. Objectively speaking, it significantly enhances the real estate prices to make buyers when buying houses encounter the problem of repetition pay of real estate tax. Also it leads to a huge burden on buyers in housing consumption.

On the other hand, tax retained link in China's real estate market is scarce. Real estate tax is basically levied in the trading link. This leads to the formation of the phenomenon that if people do not buy or rent houses, they would not have to pay real estate tax in society, the real estate tax's role of adjusting the national income, reducing the gap between rich and poor. Seen from China statistical yearbook data in 2015, the average local tax revenue of our country from $2010 \sim 2015$ was 3.012734 trillion yuan on average, among which the real estate taxes have remained in 80 billion yuan, only 3\% $\sim 4 \%$ of the local tax revenue. This shows that China's real estate tax accounts for a too small proportion in the local taxation system to form the main source of national and local income, having insignificant effect on local economic development. This environment led to frequent appearance of free riding, improper investment overheating in our country's real estate market in recent years, causing high prices of houses without effective control. It makes circulation taxes not able to get stable equilibrium and stay high all the time. But at this point, real estate developers can transfer high tax bearings onto the buyers, reducing their development costs through improving the housing prices. The serious defects of this real estate tax design also make the social and economic development in disorder.

From the angle of the real estate tax elements design, problems should be found out through three aspects including collection objects, taxation basis and tax rate.

First of all, main collection objects of the current domestic real estate tax are town business real estate items. But there are relatively more preferential policies for people outside the collection of objects, such as national financial sector will allocate the funds to the unit of the state organs, the armed forces, people's organizations to realize the real estate tax levy free, while as places of interest, park, the religious temple could realize real estate tax pat through self-use non business use fee. So, the real estate tax levy range of our country is relatively too narrow to play the reality role of adjusting the macroscopic market economy. Overall, the real estate tax levy objects allocation is unfair.

The second is the problem of taxation basis. At present our country's current real estate tax taxation basis is mainly for housing residual value. But in fact house residual value can not accurately reflect the current actual value of house. Although the problems of house depreciation will appear as time increases, actually house's surrounding environment, the change and perfection of the public facilities also influence the key values of our country at present. At this point taxation basis will not be able to provide effective judgment for housing residual value. Seen from the current real estate market development condition in China, many real estate values have been much higher than the original value of houses. But after real estate is undervalued, an accurate taxation basis can be given. If one continued to use the residual value as the real estate tax levy standard, a large number of real estate tax invalid loss would be caused.

Then is the tax rate. Except for the pilot cities, the rate proportion of which is relative standard in our country, most cities because of the uneven economic development gap are unable to objectively reflect the real estate tax levy tax standards, this once again leading to the unfair tax policy. Beyond this lateral comparison, for the longitudinal comparison, because of the high income gap of urban population in our country, while their proportion of the real estate tax is the same, this leading to the loss of the real estate tax's role of adjusting gap between the rich and the poor. Look at pilot cities' real estate tax rate adjustment, in Shanghai, for example, compared to the high value of property, the existing trial tax rate standard is relatively low, not able to form influence in house price ratio. In the first half of 2015, Shanghai's tax revenue is 973.9143 billion yuan, among which real estate tax revenue is 5.1003 billion yuan, only $0.52 \%$ of the local tax revenue. The data shows that the real estate tax rate of the pilot cities did not bring obvious benefits for local governments, it is related to too narrow scope of the real estate tax levy the above mentioned. 


\section{The real estate tax system supporting system}

Objectively speaking, China's real estate management has long had the problem of registration system missing which brings great inconvenience for tax collection work, a block for implementation of real estate tax reform. Many buyers have multiple sets of real estate tax, while able to successfully avoiding tax, this shows that there are serious problems in the assessment of real estate tax levy of our country. In fact, the current real estate tax assessment system is applied only to special assessment on old house and second-hand house, it can be seen obviously that the targeted range is imperfect, some taxpayers hide the actual price of the real estate so as to avoid appraisal mechanism's effective evaluation, this directly leads to national tax loss. So the country must make reform measures to perfect the property tax levy assessment process and method, making it fair and open during the assessment process, perfecting our laws and regulations so as to provide effective basis for tax process of property tax system. This is also a rational optimization of real estate supporting tax system environment[1].

\section{The perfect strategies for our country's real estate tax system reform}

\section{Realizing the effective simplification of real estate tax type}

Seen from the current development situation, there are too many levying tax types in our country's real estate market. It has caused a rising tax burden on taxpayers, which is not conducive to real estate resources to be effectively circulated in the market, nor the effective control of market prices. So it is necessary to effectively simplify the tax type in real estate tax, such as transferring the non-tax revenue--land transfer fee to the main tax system which can solve the unfavourable problem of the land resource sustainable development. This article suggests that adjust the original land transfer fee system into land transfer fee annual rent system. In this way, some high land use fee can be shared by every year. To some extent, the taxpayers' pressure can be reduced, while the cost of real estate at the development stage and the sales price at the property sales phase can be reduced. Besides, this system reform can certain benefit both the local governments' continuous income protection and earth use efficiency improvement to some extent. What's more, it can especially promote the perfection of the local estate keeping system, providing advantageous basis for advancing the real estate tax reform to achieve the final optimization results, also solving the central and local government real estate tax and total tax allocation problem[2].

\section{Effectively improving the real estate tax levy elements design}

As mentioned above, China's real estate tax elements design involves the collection of objects, taxation basis and tax rate, therefore in the process of tax reform effective optimization should be carried out for these three points.

First looking at the real estate tax levy objects, expanding the scope of tax collection must be taken as the first step in the whole reform to solve the problem of current collection object scope too narrow. For the ascertainment of the range of collection objects, first the basic principles of justice should be in lined with to ensure the expansion of levy range under the premise condition of ensuring the national real estate tax amount size. In particular, the country should see our country's present real estate market prices rising and buyers purchasing power declining trend, comprehensively considering the change of purchaser's comprehensive bearing capacity of the price of the house. If when purchaser bearing high house price burden at the same time increasing the real estate tax burden, the collapse and unstable phenomenon of the social economy would certain be caused. Therefore, it is necessary to retain business housing property tax levy standard for low and middle income earners, implementing pilot property tax levy starting with buyers with more houses or high-end luxury housing, according to the tax situation, and then gradually adjusting the range of tax levy, expanding the levy range according to the residents' income level gradually. While the final objective can be considered to expand the levy range to the outside region of the town to realize nationwide coverage. 
Second looking at the taxation basis, considering residual value cannot reflect the real estate property existing value, so real estate estimate value strategy should be taken to support the real estate levy in the pilot cities, that is, perfecting the real estate evaluation system. Because the property's value is constantly changing, the relevant departments must implement the regularly repeat assessment of the value of property with the purpose of ensuring the accuracy, fairness and authenticity of the property's value could be kept any time. Therefore, our country can draw lessons from the abroad practice and experience in real estate assessment, such as cost method, market value method and so on etc. which can effectively reflect the residual value of the real estate market. Combined again with our country's condition and assessment system to classify rates for houses, finally realizing scientific and accurate determination of estate assessed value. If temporarily the market transaction were unable to be used to determine the market value of the estate, property values should be estimated according to replacement cost and future prospective earnings to ensure the housing estimated value real and accurate.

The last is the tax rate, now China's real estate tax system in the aspect of regulation of tax rate is relatively single, basically not able to play a regulation role in view of the real estate tax regulation. Therefore graduated tax rates need to be considered to be used to replace single rate. On this issue, at present Chongqing has started to formulate different tax rate according to different property type, and further realizing hierarchical property tax levy. For example, it can be divided into office space and living housing property tax levy, thereamong the living housing can be divided into three types: Senior housing, ordinary housing and affordable housing. Different tax rate is determined by different value of different property type. Besides, the real estate tax rate should be adjusted according to the economic development and the real estate market policy from place to place, the premise is, making sure that the tax is within the range of the national fixed real estate tax levy. On considering that the owners of multiple houses and high-grade property may have overinvestment behavior, therefore , in this way, the real estate tax rate can be effectively adjusted. To sum up, the adjustment of tax rate must be within taxpayer's affordable range, expanding the levy proportion of tax rate effectively to make it really able to regulate the real estate market macroeconomic.

\section{Realizing the optimal construction of affordable housing}

We should pay attention to the diversity goals of real estate tax system reform, should not only regard it as the principal means of lowering prices in regulating the real estate market, but should also consider to apply it to optimal construction of affordable housing so as to ensure the effective supply regulation of affordable housing to solve the housing problems of low-income urban residents. In Shanghai, for example, since 2011, Shanghai began to implement "high-end constraint, midrange and low-end security" of the real estate tax system reform optimal policy. Its core idea is to leverage local real estate market regulation and strengthen the main position of ordinary commercial housing in the market, restricting high-end real estate market around the mid-market at the same time balancing the low-end economy housing real estate tax system. It can be seen that real estate tax system reform is necessary for the urban ensuring housing construction optimization. It can both ensure the basic quality of the urban residents living, and let people further agree the real estate tax. It should regarded as the cornerstone of our real estate tax system reform[3].

\section{Conclusion}

Seen from the current situation of development, China's real estate tax system reform process still exists many disputes and practical implementation problems. This paper puts forward the problems and strategies on real estate tax system reform in China, hoping to make people realize the important influence of this problem on the social development construction of our country, pushing forward the new ideas and new system of real estate tax system reform through the reform of trial practice. Also low-end users' demand should be paid more attention to, building a comprehensive, unified and complete and humanized new real estate tax revenue system. 


\section{References}

[1] Song Zhe, China's real estate tax reform research, Liaoning normal university, 2011.11-13.

[2] Song Zhe, Tian-jian Li, Real estate tax reform and impact analysis, Journal of information science and technology, 2010 (24) : 359-360.

[3] Niu Huanhuan, Shanghai Chongqing real estate tax reform and the economic effect analysis, Shandong university, 2013.40-44 